\title{
Demethylation of Methylated Arsenic Species during Generation of Arsanes with Tetrahydridoborate(1-) in Acidic Media
}

Karel Marschner* ${ }^{\dagger},+$, Stanislav Musil ${ }^{\dagger}$, Jiří Dědina ${ }^{\dagger}$

${ }^{\dagger}$ Institute of Analytical Chemistry of the CAS, v. v. i., Veveř́ 97, 60200 Brno, Czech Republic

Department of Analytical Chemistry, Faculty of Science, Charles University in Prague, Albertov 8, 12843 Prague, Czech Republic

*Corresponding author; E-mail: karel.marschner@biomed.cas.cz

\section{Abstract of Supporting Information}

Supporting Information includes details on dependences of demethylation of $\mathrm{DMAs}^{\mathrm{V}}$ and $\mathrm{TMAs}^{\mathrm{V}} \mathrm{O}$. Namely, it contains dependences on concentration of $\mathrm{HCl}, \mathrm{THB}$, experiments with hydrolysis coil (HC), and demethylation of $\mathrm{TMAs}^{\mathrm{V}} \mathrm{O}$ on concentration of $\mathrm{HNO}_{3}$.

\section{Effect of HCl Concentration}

The dependences of arsane fractions formed from DMAs ${ }^{\mathrm{V}}$ and $\mathrm{TMAs}^{\mathrm{V}} \mathrm{O}$ on concentration of $\mathrm{HCl}$ are shown in Figure S-1(a,b). 
a)

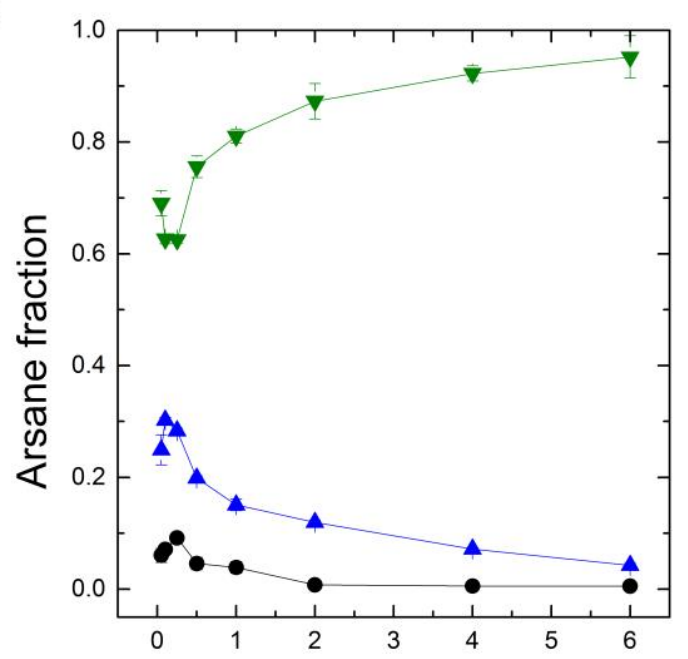

Concentration of $\mathrm{HCl}, \mathrm{mol} \mathrm{L}^{-1}$ b)

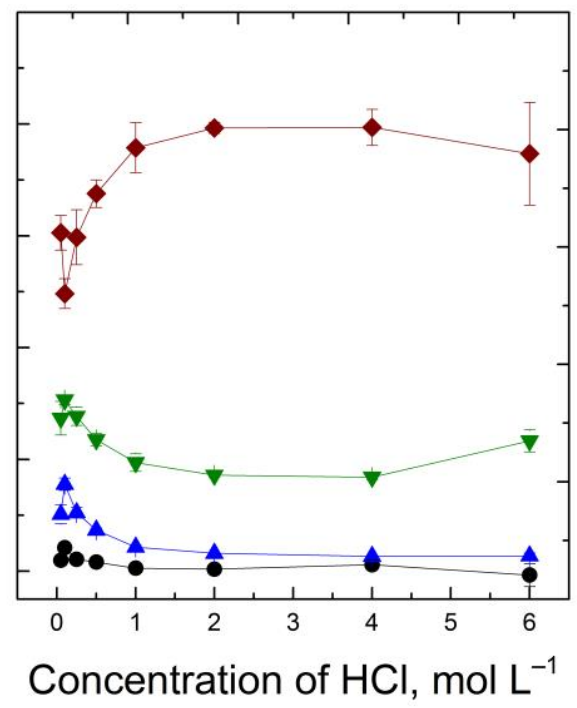

Figure S-1 Dependence of arsane fractions formed from (a) DMAs ${ }^{\mathrm{V}}$ and (b) TMAs $^{\mathrm{V}} \mathrm{O}$ on concentration of $\mathrm{HCl}$; (black) $\bullet-\mathrm{AsH}_{3}$, (blue) $\boldsymbol{\Delta}-\mathrm{CH}_{3} \mathrm{AsH}_{2}$, (green) $\boldsymbol{\nabla}-\left(\mathrm{CH}_{3}\right)_{2} \mathrm{AsH}$ and (brown) - $\left(\mathrm{CH}_{3}\right)_{3} \mathrm{As}$; concentration of DMAs ${ }^{\mathrm{V}}$ species was $0.5 \mathrm{ng} \mathrm{mL}^{-1}$, concentration of TMAs $^{\mathrm{V}} \mathrm{O}$ was $0.5 \mathrm{ng} \mathrm{mL}^{-1}$ for $\mathrm{HCl}$ concentration range from 0.05 to $1.0 \mathrm{~mol} \mathrm{~L}^{-1}$ and $2.0 \mathrm{ng}$ $\mathrm{mL}^{-1}$ for $\mathrm{HCl}$ concentration range from 2.0 to $6.0 \mathrm{~mol} \mathrm{~L}^{-1}, 1 \mathrm{~mL}$ of $1 \%$ THB addition.

\section{Effect of THB Concentration}

The dependences of arsane fractions formed from DMAs ${ }^{\mathrm{V}}$ and $\mathrm{TMAs}^{\mathrm{V}} \mathrm{O}$ on concentration of THB are shown in Figure S-2(a,b). 
a)

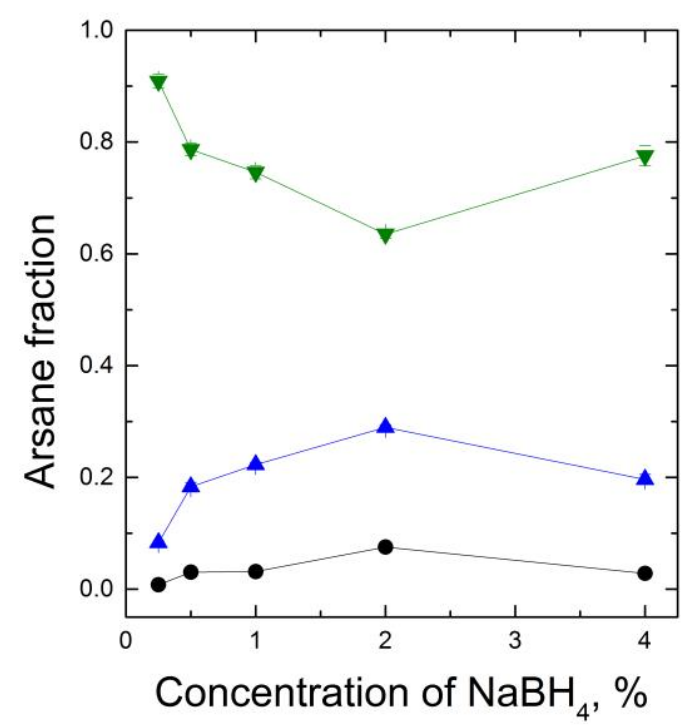

b)

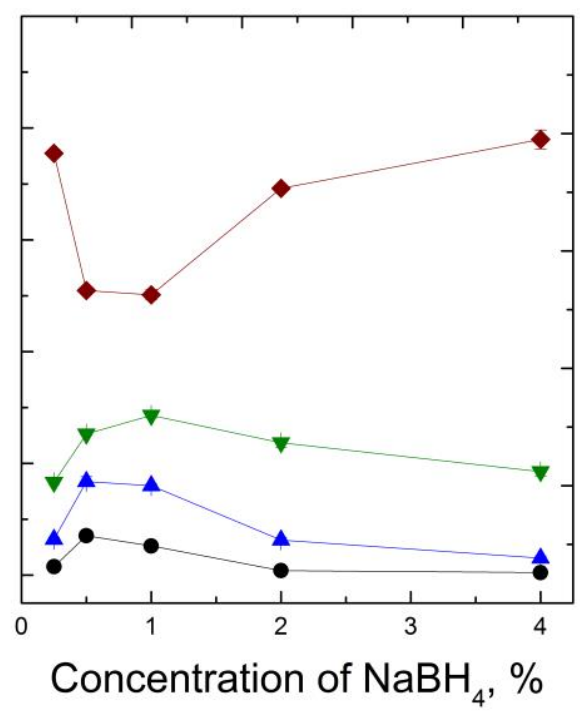

Figure S-2 Dependence of arsane fractions formed from (a) DMAs ${ }^{\mathrm{V}}$ and (b) TMAs ${ }^{\mathrm{V}} \mathrm{O}$ on concentration of THB; (black) $\bullet-\mathrm{AsH}_{3}$, (blue) $\boldsymbol{\Delta}-\mathrm{CH}_{3} \mathrm{AsH}_{2}$, (green) $\boldsymbol{\nabla}-\left(\mathrm{CH}_{3}\right)_{2} \mathrm{AsH}$ and (brown) - $\left(\mathrm{CH}_{3}\right)_{3} \mathrm{As}$; concentration of As species was $0.5 \mathrm{ng} \mathrm{mL} \mathrm{m}^{-1}, 0.25 \mathrm{~mol} \mathrm{~L}^{-1} \mathrm{HCl}, 1 \mathrm{~mL}$ of $1 \%$ THB addition.

\section{Prereaction of $\mathrm{THB}$ with $\mathrm{HCl}$}

The dependences of arsane fractions formed from DMAs ${ }^{\mathrm{V}}$ and $\mathrm{TMAs}^{\mathrm{V}} \mathrm{O}$ on concentration of $\mathrm{HCl}$ used for prereaction are shown in Figure S-3(a,b). 
a)

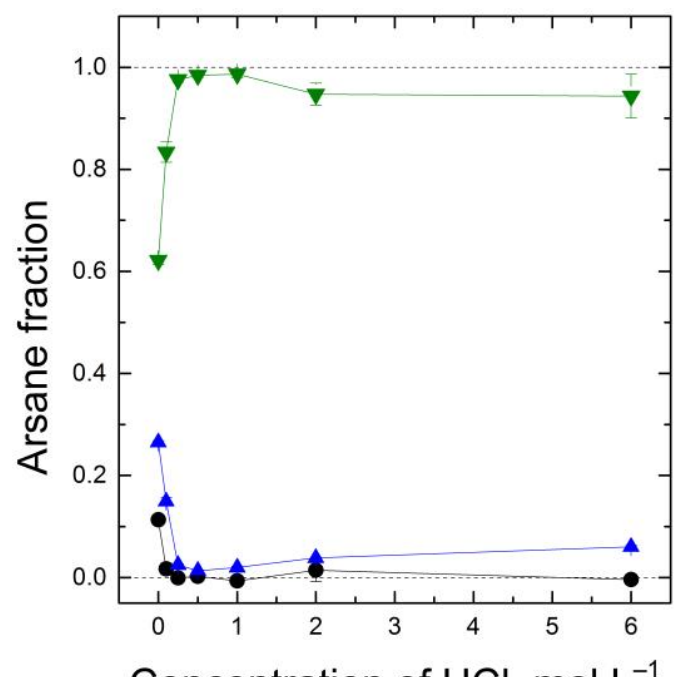

b)

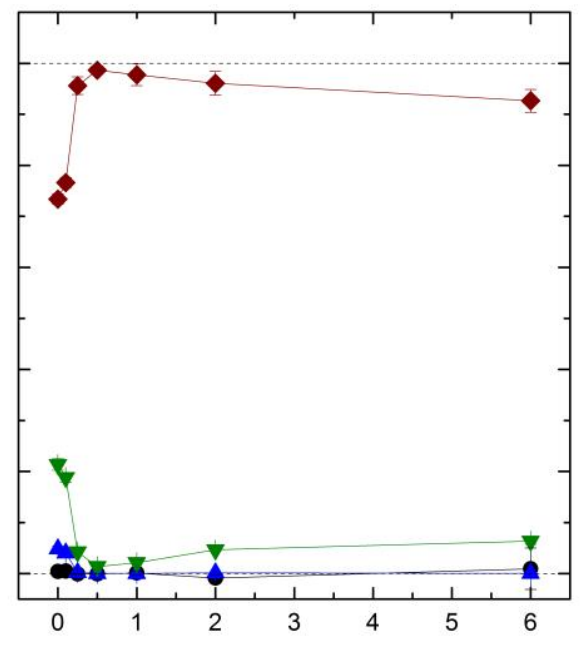

Concentration of $\mathrm{HCl}$, $\mathrm{mol} \mathrm{L}^{-1}$

Figure S-3 Dependence of arsane fractions formed from (a) DMAs ${ }^{\mathrm{V}}$ and (b) TMAs ${ }^{\mathrm{V}} \mathrm{O}$ on concentration of $\mathrm{HCl}$ used for prereaction of THB; (black) $\bullet-\mathrm{AsH}_{3}$, (blue) $\boldsymbol{\Delta}-\mathrm{CH}_{3} \mathrm{AsH}_{2}$, (green) $\boldsymbol{\nabla}-\left(\mathrm{CH}_{3}\right)_{2} \mathrm{AsH}$ and (brown) $-\left(\mathrm{CH}_{3}\right)_{3} \mathrm{As}$; HC volume was $40 \mu \mathrm{L}$, concentration of DMAs $^{\mathrm{V}}$ species was $0.5 \mathrm{ng} \mathrm{mL}{ }^{-1}$, concentration of $\mathrm{TMAs}^{\mathrm{V}} \mathrm{O}$ was $0.5 \mathrm{ng} \mathrm{mL}{ }^{-1}$ for $\mathrm{HCl}$ concentration range from 0 to $1.0 \mathrm{~mol} \mathrm{~L}^{-1}$ and $2.0 \mathrm{ng} \mathrm{mL}^{-1}$ for $\mathrm{HCl}$ concentration range from

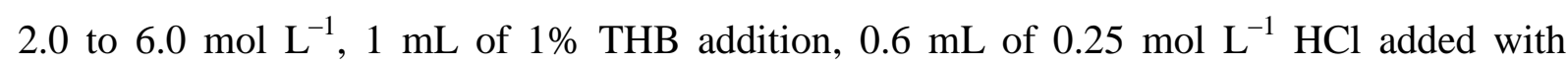
standard.

\section{Nitric Acid}

The dependences of arsane fractions formed from TMAs ${ }^{\mathrm{V}} \mathrm{O}$ on concentration of $\mathrm{HNO}_{3}$ are shown in Figure S-4. The linear regression of points for $\left(\mathrm{CH}_{3}\right)_{3}$ As gives an equation $\mathrm{y}=-$ $0.061 \mathrm{x}+0.998$ with $\mathrm{R}^{2}=0.9902$ while for $\left(\mathrm{CH}_{3}\right)_{2} \mathrm{AsH}$ it gives an equation $\mathrm{y}=0.059 \mathrm{x}+0.006$ with $\mathrm{R}^{2}=0.9902$. This shows good linearity between demethylation and concentration of $\mathrm{HNO}_{3}$. 


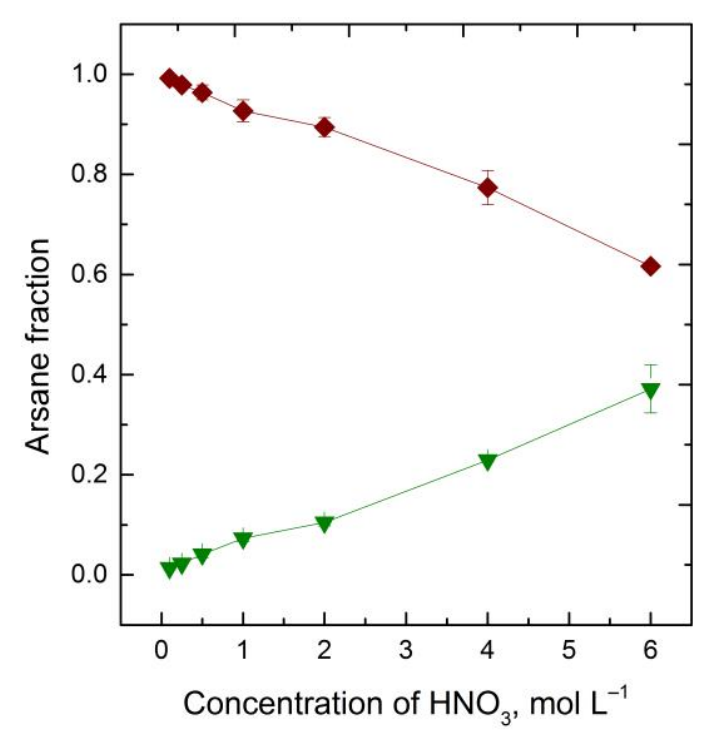

Figure S-4 Dependence of arsane fractions formed from $\mathrm{TMAs}^{\mathrm{V}} \mathrm{O}$ on concentration of $\mathrm{HNO}_{3}$; (green) $\boldsymbol{\nabla}-\left(\mathrm{CH}_{3}\right)_{2} \mathrm{AsH}$ and (brown) $-\left(\mathrm{CH}_{3}\right)_{3} \mathrm{As}$; concentration of DMAs ${ }^{\mathrm{V}}$ species was 0.5 ng mL ${ }^{-1}$, concentration of $\mathrm{TMAs}^{\mathrm{V}} \mathrm{O}$ was $0.5 \mathrm{ng} \mathrm{mL}{ }^{-1}$ for $\mathrm{HNO}_{3}$ concentration range from 0.1 to $1.0 \mathrm{~mol} \mathrm{~L}^{-1}$ and $2.0 \mathrm{ng} \mathrm{mL}^{-1}$ for $\mathrm{HNO}_{3}$ concentration range from 2.0 to $6.0 \mathrm{~mol} \mathrm{~L}^{-1}, 1 \mathrm{~mL}$ of $1 \%$ THB addition. 